TITLE:

\title{
Kinetic analysis of reverse transcriptase activity of bacterial family A DNA polymerases.
}

\section{$\operatorname{AUTHOR(S):~}$}

Yasukawa, Kiyoshi; Konishi, Atsushi; Shinomura, Mayu; Nagaoka, Eriko; Fujiwara, Shinsuke

\section{CITATION:}

Yasukawa, Kiyoshi ...[et al]. Kinetic analysis of reverse transcriptase activity of bacterial family A DNA polymerases.. Biochemical and biophysical research communications 2012, 427(3): 654-658

\section{ISSUE DATE:}

2012-10-26

URL:

http://hdl.handle.net/2433/161657

\section{RIGHT:}

(C) 2012 Elsevier Inc.; This is not the published version. Please cite only the published version.; この論文は出版社版でありません。引用の際に は出版社版をご確認ご利用ください。 
1 Biochem. Biophys. Res. Commun.

2

3 Kinetic analysis of reverse transcriptase activity of bacterial family A DNA

polymerases

5

6 Kiyoshi Yasukawa ${ }^{\mathrm{a}, *}$, Atsushi Konishi ${ }^{\mathrm{a}}$, Mayu Shinomura ${ }^{\mathrm{a}}$, Eriko Nagaoka ${ }^{\mathrm{b}}$,

$7 \quad$ Shinsuke Fujiwara ${ }^{\text {b,c }}$

8

$9{ }^{\mathrm{a}}$ Division of Food Science and Biotechnology, Graduate School of Agriculture, Kyoto

University, Sakyo-ku, Kyoto 606-8502, Japan

11 bepartment of Bioscience, Graduate School of Science and Technology,

12 Kwansei-Gakuin University, 2-1 Gakuen, Sanda, Hyogo 669-1337, Japan

$13{ }^{\mathrm{c}}$ Research Center for Environmental Bioscience, Graduate School of Science and

14 Technology, Kwansei-Gakuin University, 2-1 Gakuen, Sanda, Hyogo 669-1337, Japan

* Corresponding author. Fax: +81-75-753-6265.

$17 \quad$ E-mail address: yasukawa@kais.kyoto-u.ac.jp (K. Yasukawa)

Abbreviations: K4pol, family A DNA polymerase from Thermotoga petrophila strain sulfate-polyacrylamide gel electrophoresis. 
1 Some bacterial thermostable, wild-type or genetically engineered family A DNA

2 polymerases have reverse transcriptase activity. However, difference in reverse

3 transcriptase activities of family A DNA polymerases and retroviral reverse

4 transcriptases (RTs) is unclear. In this study, comparative kinetic analysis was

5 performed for the reverse transcriptase activities of the wild-type enzyme of family A

6 DNA polymerase (M1pol $\left.{ }_{\mathrm{WT}}\right)$ from Thermus thermophilus $\mathrm{M} 1$ and the variant enzyme of

7 family A DNA polymerase $\left(\mathrm{K} 4 \mathrm{pol}_{\mathrm{L} 329 \mathrm{~A}}\right)$, in which the mutation of Leu329 $\rightarrow$ Ala is

8 undertaken, from Thermotoga petrophila K4. In the incorporation of dTTP into

9 poly(rA)-p(dT) ${ }_{45}$, the reaction rates of $\mathrm{K} 4 \mathrm{pol}_{\mathrm{L} 329 \mathrm{~A}}$ and $\mathrm{M} 1 \mathrm{pol}_{\mathrm{WT}}$ exhibited a saturated

10 profile of the Michaelis-Menten kinetics for dTTP concentrations but a substrate

11 inhibition profile for poly $(\mathrm{rA})-\mathrm{p}(\mathrm{dT})_{45}$ concentrations. In contrast, the reaction rates of

12 Moloney murine leukemia virus (MMLV) RT exhibited saturated profiles for both dTTP

13 and poly(rA)-p(dT) 45 concentrations. This suggests that high concentrations of

14 DNA-primed RNA template decrease the efficiency of cDNA synthesis with bacterial

15 family A DNA polymerases.

16

17 Keywords: family A DNA polymerase; Moloney murine leukemia virus; reverse 18 transcriptase; template-primer; Thermotoga petrophila; Thermus thermophilus. 


\section{Introduction}

(1)

3

RNA secondary structure and nonspecific binding of the primer. Reverse transcriptases

(RTs) from Moloney murine leukemia virus (MMLV) and Avian myeloblastosis virus

(AMV) have been used in cDNA synthesis. MMLV RT and AMV RT are not

thermostable. To realize the cDNA synthesis reaction at high temperature, their thermal stabilities were improved by eliminating the RNase $\mathrm{H}$ activity [1], random mutation [2], and site-directed mutagenesis $[3,4]$. cDNA synthesis with thermostable RTs are carried out at around $50^{\circ} \mathrm{C}$.

Some bacterial or archaeal, wild-type or genetically engineered DNA polymerases have RNA-dependent DNA polymerase (reverse transcriptase) activity [5-8]. One of the advantages of such DNA polymerases over retroviral RTs are that the DNA polymerases are stable even at around $90^{\circ} \mathrm{C}$, enabling direct RT-PCR in a single tube [6-8]. Figure 1A shows domain structure of DNA polymerases. The proofreading 3'-5' exonuclease domain confers high fidelity. Bacterial family A DNA polymerases, such as from Thermus thermophilus and Thermus aquaticus, do not have the 3'-5' exonuclease domain and exhibit reverse transcriptase activity. Bacterial family A DNA polymerases, such as from Thermotoga petrophila and Thermotoga maritime have the 3'-5' exonuclease domain and do not exhibit reverse transcriptase activity. Archaeal family B DNA polymerases, such as Thermococcus kodakarensis and Pyrococcus furiosus, have the 3'-5' exonuclease domain and exhibit reverse transcriptase activity. However, family B DNA polymerases are not suitable in cDNA synthesis because the reaction stops when a uracil-containing template is incorporated [9]. 
Figure 1B shows the modeled structure of Family A DNA polymerase (K4pol)

2 from Thermotoga petrophila K4. Nine residues (Tyr326, Leu329, Gln384, Lys387,

3 Phe388, Met408, Asn422, Tyr438, and Phe451) are predicted to be involved in

4 DNA/RNA distinction. Figure $1 \mathrm{C}$ and $\mathrm{D}$ show that the steric hindrance with the

5 2'-hydroxyl group of ribose in K4pol might be removed by the mutation of

6 Leu329 $\rightarrow$ Ala. Previous site-directed mutagenesis study revealed that six variants

7 (Y326A, L329A, Q384A, F388A, M408A, and Y438A) exhibited the reverse

8 transcriptase activity [10]. However, the threshold PCR cycle numbers needed to reach

9 the constant fluorescent intensity in the direct RT-PCR with these variants were higher

10 by $5-10$ cycles than that in the conventional RT-PCR using MMLV RT in cDNA synthesis and family B DNA polymerase from hyperthermophilic archaeon Thermococcus kodakaraensis in the subsequent PCR [10]. This indicates that cDNA synthesis with these variants is less efficient than that with MMLV RT. In this study, to address this issue, we made kinetic analysis of the reverse transcriptase activities of the wild-type enzyme of family A DNA polymerase (M1pol ${ }_{\mathrm{WT}}$ ) from T. thermophilus M1 and the variant enzyme of $\mathrm{K} 4 \mathrm{pol}\left(\mathrm{K} 4 \mathrm{pol}_{\mathrm{L} 329 \mathrm{~A}}\right)$ in which the mutation of Leu329 $\rightarrow \mathrm{Ala}$ is undertaken. The results have shown that high concentrations of DNA-primed RNA template decrease their reverse transcriptase activities.

\section{Materials and methods}


1 BL21(DE3) codon plus [F ompT $h s d S\left(\mathrm{r}_{\mathrm{B}}{ }^{-} \mathrm{m}_{\mathrm{B}}{ }^{-}\right) d c m^{+} \operatorname{Tet}^{r}$ gald (DE3) endA Hte [argU

2 proL $\left.\mathrm{Cam}^{r}\right]$ ] (Agilent Technologies) was transformed with the pET-21a plasmid

3 harboring the $\mathrm{K}_{4} \mathrm{pol}_{\mathrm{L} 329 \mathrm{~A}}$ gene. The $\mathrm{K} 4 \mathrm{pol}_{\mathrm{L} 329 \mathrm{~A}}$ was expressed in the soluble fraction of

4 the transformants. After the heat treatment of the soluble fraction at $85^{\circ} \mathrm{C}$ for $30 \mathrm{~min}$,

5 the enzyme was purified. The enzyme concentration was determined by the method of

6 Bradford [11] using Protein Assay CBB Solution (Nacalai Tesque, Kyoto, Japan) with

7 bovine serum albumin (Nacalai Tesque) as standard.

\subsection{Expression and purification of recombinant form of $M M L V R T$}

Recombinant MMLV RT was prepared as described previously [3]. Briefly, E. coli strain BL21(DE3) was transformed with the pET-22b plasmid harboring the gene encoding the C-terminally His ${ }_{6}$-tagged MMLV RT. The MMLV RT was expressed in the soluble fraction of the transformants, from which active enzyme was purified.

\subsection{Expression and purification of recombinant form of $\mathrm{M}^{1} \mathrm{pol}_{\mathrm{WT}}$}

T. thermophilus strain M1 was isolated from a hot spring $\left(73^{\circ} \mathrm{C}\right)$ at Kagoshima (Japan) and identified as T. thermophilus based on 16S rDNA sequence. Amino acid sequence of DNA polymerase and nucleotide sequence of 16S rDNA from M1 show the highest identity to those of T. thermophilus HB8 (99\% and 98\%, respectively). DNA polymerase gene $(\mathrm{Mlpol})$ of M1 was amplified by PCR using oligonucleotide primers 
1 as a template. PCR was performed using 1 unit of KOD Plus polymerase (Toyobo,

2 Osaka, Japan) under following condition $\left(3 \mathrm{~min}\right.$ at $94^{\circ} \mathrm{C}$, followed by 30 cycle of $15 \mathrm{~s}$ at $94^{\circ} \mathrm{C}, 30 \mathrm{~s}$ at $50^{\circ} \mathrm{C}, 3 \mathrm{~min}$ at $68^{\circ} \mathrm{C}$ ). The amplified DNA was digested with restriction enzymes $N d e I$ and EcoRI, and the obtained DNA was inserted into the pET-28a digested with the same enzymes. The resultant plasmid was designed as pET-M1pol. BL21(DE3) codon plus was transformed with pET-M1pol. The transformants were aerobically grown at $30^{\circ} \mathrm{C}$ in $300 \mathrm{ml}$ of LB medium ( $1 \%$ tryptone, $0.5 \%$ yeast extract, $1 \% \mathrm{NaCl}$; adjusted to $\mathrm{pH} 7.3$ with $\mathrm{NaOH}$ ) containing $20 \mu \mathrm{g} / \mathrm{ml}$ kanamycin and $30 \mu \mathrm{g} / \mathrm{ml}$ chloramphenicol to $O D_{660}$ of 0.4 . IPTG was then added to the final concentration of 1 $\mathrm{mM}$. The cells were further incubated at $30^{\circ} \mathrm{C}$ for $4 \mathrm{~h}$ and were harvested by centrifugation $(8,000 \times \mathrm{g}, 10 \mathrm{~min})$. The cells were resuspended in $7 \mathrm{ml}$ of buffer $\mathrm{A}(20$ $\mathrm{mM}$ Tris- $\mathrm{HCl}, 500 \mathrm{mM} \mathrm{NaCl}, 5 \mathrm{mM}$ imidazole, $0.1 \%$ Triton $\mathrm{X}-100, \mathrm{pH} \mathrm{7.9)}$ and disrupted by sonication. The lysate was then separated by centrifugation $(8,000 \times \mathrm{g}, 10$ min). The obtained supernatant was heated at $75^{\circ} \mathrm{C}$ for $30 \mathrm{~min}$ and centrifuged again $(8,000 \times \mathrm{g}, 10 \mathrm{~min})$. The supernatant was applied to a $\mathrm{Ni}^{2+}-\mathrm{TED}$ Sepharose column equilibrated with buffer A. Next, the column was washed several times with the same buffer. The N-terminally His 6 -tagged $T$. thermophilus M1 DNA polymerase (M1pol ${ }_{\mathrm{WT}}$ ) was eluted with buffer B (20 mM Tris- $\mathrm{HCl}, 500 \mathrm{mM} \mathrm{NaCl}, 100 \mathrm{mM}$ imidazole, $0.1 \%$ Triton $\mathrm{X}-100, \mathrm{pH}$ 7.9). The active fractions were pooled and dialyzed against a buffer containing $20 \mathrm{mM}$ Tris- $\mathrm{HCl}, 500 \mathrm{mM} \mathrm{NaCl}, \mathrm{pH} 7.9$.

\subsection{Nucleotide sequence accession number}

The nucleotide sequences of DNA polymerase and $16 \mathrm{~S}$ rDNA from $T$. 
1 thermophilus $\mathrm{M} 1$ reported in this study have been submitted to the DDBJ nucleotide

2 sequence database under the accession numbers AB744210 and AB744654,

3 respectively.

4

$5 \quad$ 2.5. DNA-dependent DNA polymerase assay

6

7 DNA-dependent DNA polymerase activity to incorporate dNTP into gapped

8 M13mp2 DNA was examined as described previously [12,13]. Briefly, the 6,789-bp

9 fragment was obtained by the digestion of the 7,196-bp double-strand circular M13mp2

10 DNA with $P v u \mathrm{II}$ and the precipitation by $6 \% \mathrm{w} / \mathrm{v}$ polyethylene glycol-8000, $550 \mathrm{mM}$

$11 \mathrm{NaCl}$. The gapped DNA was prepared by the annealing of the 7,196-base single-strand circular M13mp2 DNA (140 $\mu \mathrm{g}$ in $10 \mathrm{mM}$ Tris-HCl, $\mathrm{pH}$ 8.0) with the heat-denatured 6,789-bp fragment (150 $\mu \mathrm{g}$ in $10 \mathrm{mM}$ Tris- $\mathrm{HCl}, \mathrm{pH} 8.0)$. The reaction $(15 \mu \mathrm{L})$ was carried out with $670 \mathrm{nM} \mathrm{K} 4 \mathrm{pol}_{\mathrm{L} 329 \mathrm{~A}}$ and $57 \mu \mathrm{g}$ of gapped DNA in $50 \mathrm{mM}$ bicine- $\mathrm{KOH}$, $1 \mathrm{mM} \mathrm{Mn}\left(\mathrm{CH}_{3} \mathrm{COO}\right)_{2}, 115 \mathrm{mM} \mathrm{CH}_{3} \mathrm{COOK}, 8 \%$ glycerol at $\mathrm{pH} 8.2$ (buffer B) at $70^{\circ} \mathrm{C}$. The reaction products $(13 \mu \mathrm{L})$ were applied to $0.8 \%$ agarose gel, followed by staining with ethidium bromide $(1 \mu \mathrm{g} / \mathrm{ml})$.

\subsection{Reverse transcriptase assay}

Reverse transcriptase activity to incorporate dTTP into poly(rA)-p(dT) ${ }_{45}$ was examined, based on the previous method using poly(rA)-p(dT) ${ }_{15}[3,4]$. Briefly, $2.0 \mathrm{mM}$ poly $(\mathrm{rA})-\mathrm{p}(\mathrm{dT})_{45}(\mathrm{~T} / \mathrm{P})$ (the concentration is expressed as that of $\mathrm{p}(\mathrm{dT})_{45}$ ) was prepared 
1 by mixing $300 \mu \mathrm{L}$ of $2.5 \mathrm{mM}$ p $(\mathrm{dT})_{45}$ (Sigma-Aldrich Japan, Ishikari, Japan) and $75 \mu \mathrm{L}$

2 of $100 \mathrm{mM}$ poly(rA) (the concentration is expressed as that of $\mathrm{rA}$ ) (GE Healthcare,

3 Buckinghamshire, UK) followed by the incubation at $70^{\circ} \mathrm{C}$ for $15 \mathrm{~min}$ and at room

4 temperature for $30 \mathrm{~min}$. $\left[{ }^{3} \mathrm{H}\right] \mathrm{dTTP}(1.85 \mathrm{~Bq} / \mathrm{pmol})$ was prepared by mixing $860 \mu \mathrm{L}$ of

$5 \quad$ water, $100 \mu \mathrm{L}$ of $\left[{ }^{3} \mathrm{H}\right] \mathrm{dTTP}(1.52 \mathrm{TBq} / \mathrm{mmol})$ (GE Healthcare), and $40 \mu \mathrm{L}$ of $100 \mathrm{mM}$

6 dTTP (GE Healthcare). The reaction was carried out with various concentrations of

7 dTTP and T/P in buffer $\mathrm{B}$ at $50^{\circ} \mathrm{C}$ for $\mathrm{K} \mathrm{pol}_{\mathrm{L} 329 \mathrm{~A}}$ and $\mathrm{M} 1 \mathrm{pol}_{\mathrm{WT}}$, or in $25 \mathrm{mM}$ Tris- $\mathrm{HCl}$,

$850 \mathrm{mM} \mathrm{KCl}, 2 \mathrm{mM}$ dithiothreitol, $5 \mathrm{mM} \mathrm{MgCl}_{2}, \mathrm{pH} 8.3$ at $37^{\circ} \mathrm{C}$ for MMLV RT.

\section{Results}

\subsection{DNA- and RNA-dependent DNA polymerase activities of K4pol ${ }_{L 329 A}$}

Recombinant K4pol ${ }_{\mathrm{L} 329 \mathrm{~A}}$, MMLV RT, and M1polwT were expressed in E. coli and purified from the soluble fractions of the cells. Figure 2A shows the result of SDS-PAGE analysis of purified enzyme preparations. The preparations of K4pol ${ }_{\mathrm{L} 329 \mathrm{~A}}$, MMLV RT, and M1polwT yielded a single band with a molecular mass of 101, 75, and $90 \mathrm{kDa}$, respectively. Figure 2B shows the result of DNA-dependent DNA polymerase assay. In this assay, the 407-base gap of the 7,196-bp double-strand circular M13mp2 DNA is filled by the reaction with DNA polymerase. The reaction product with $\mathrm{K}_{4} \mathrm{pol}_{\mathrm{L} 32 \mathrm{~A}}$ exhibited the band corresponding to the gap-filled DNA, but did not exhibit the one corresponding to the gapped DNA. Figure $2 \mathrm{C}$ shows the result of reverse transcriptase assay. The amounts of $\left[{ }^{3} \mathrm{H}\right] \mathrm{dTTP}$ incorporated increased with increasing time in the reaction with $\mathrm{K} 4 \mathrm{pol}_{\mathrm{L} 329 \mathrm{~A}}, \mathrm{M} 1$ pol $_{\mathrm{WT}}$, and MMLV RT. But they did not 
increase with increasing time in the reaction with the wild-type $\mathrm{K} 4 \mathrm{pol}\left(\mathrm{K} 4 \mathrm{pol}_{\mathrm{WT}}\right)$. This indicates that the mutation of Leu329 $\rightarrow$ Ala does not abolish the DNA-dependent DNA polymerase activity and creates reverse transcriptase activity in K4pol.

3.2. Inhibitory effect of $T / P$ toward the reverse transcriptase activities of $K 4{ }_{p o l} l_{L 329 A}$ and $\operatorname{Mlpol}_{W T}$

Figure 3A shows the reaction rates of $\mathrm{K}^{4} \mathrm{pol}_{\mathrm{L} 329 \mathrm{~A}}$, M1 $\mathrm{pol}_{\mathrm{WT}}$, and MMLV RT for reverse transcriptase reaction at various dTTP concentrations. A saturated profile of the Michaelis-Menten kinetics were obtained, and the $K_{\mathrm{m}}$ and $k_{\text {cat }}$ values were determined to be $280 \pm 80 \mu \mathrm{M}$ and $1.7 \pm 0.3 \mathrm{~s}^{-1}$, respectively, for $\mathrm{K}^{4} \operatorname{pol}_{\mathrm{L} 329 \mathrm{~A}}, 230 \pm 70 \mu \mathrm{M}$ and $1.0 \pm$ $0.2 \mathrm{~s}^{-1}$, respectively, for M1pol ${ }_{\mathrm{wT}}$, and $250 \pm 60 \mu \mathrm{M}$ and $35 \pm 6 \mathrm{~s}^{-1}$, respectively, for MMLV RT. This indicates that the $k_{\mathrm{cat}}$ values of $\mathrm{K} \mathrm{pol}_{\mathrm{L} 329 \mathrm{~A}}$ and $\mathrm{M} 1 \mathrm{pol} \mathrm{WT}_{\mathrm{WT}}$ at $50^{\circ} \mathrm{C}$ were 5 and $3 \%$, respectively, of that of MMLV RT at $37^{\circ} \mathrm{C}$ while their $K_{\mathrm{m}}$ values were similar.

Figure 3B shows the reaction rates of $\mathrm{K}^{4} \mathrm{pol}_{\mathrm{L} 329 \mathrm{~A}}$, M1pol ${ }_{\mathrm{WT}}$, and MMLV RT for reverse transcriptase reaction at various $\mathrm{T} / \mathrm{P}$ concentrations. A substrate inhibition profile was obtained for $\mathrm{K}_{4} \mathrm{pol}_{\mathrm{L} 329 \mathrm{~A}}$ and $\mathrm{M} 1 \mathrm{pol}_{\mathrm{WT}}$ : the reaction rates reached the maximum at $10 \mu \mathrm{M} \mathrm{T} / \mathrm{P}$, decreased with increasing T/P concentration $(10-100 \mu \mathrm{M})$, and reached $50 \%$ of the maximum at $100 \mu \mathrm{M}$ T/P. On the other hand, a saturated profile of the Michaelis-Menten kinetics was obtained for MMLV RT: the $K_{\mathrm{m}}$ and $k_{\text {cat }}$ values were determined to be $5.6 \pm 0.8 \mu \mathrm{M}$ and $29 \pm 6 \mathrm{~s}^{-1}$, respectively.

\subsection{Temperature dependence of the reverse transcriptase activity of $K 4 \mathrm{pol}_{\mathrm{L329A}}$}


2 Considering that RNA is stable up to around $65^{\circ} \mathrm{C}$, the optimal reaction

3 temperature for cDNA synthesis reaction with thermostable DNA polymerases is

4 thought to be around $65^{\circ} \mathrm{C}$. However, poly $(\mathrm{rA})-\mathrm{p}(\mathrm{dT})_{45}$ dissociates at $65^{\circ} \mathrm{C}$. To estimate

5 the reverse transcriptase activity of $\mathrm{K} 4 \mathrm{pol}_{\mathrm{L} 329 \mathrm{~A}}$ at $65^{\circ} \mathrm{C}$, the reaction rates of $\mathrm{K} 4 \mathrm{pol}_{\mathrm{L} 329 \mathrm{~A}}$

6 to incorporate dTTP into T/P were measured at various temperatures (Fig. 4). They

7 increased with increasing temperature from 37 to $52^{\circ} \mathrm{C}$. Inset shows Arrhenius plot on

8 the assumption that the observed reaction rates correspond to $V_{\max }$. Linear relationship

9 was held between the natural logarithm of $V_{\max }$ and $1 / T$. In this plot, $\ln \left(V_{\max }\right)$ value of

106.4 (the $V_{\max }$ value of $600 \mathrm{nM} \mathrm{s}^{-1}$ ) was estimated at $65^{\circ} \mathrm{C}$, and the $k_{\text {cat }}$ value at $65^{\circ} \mathrm{C}$ was

11 calculated to be $12 \mathrm{~s}^{-1}$. Considering that the $k_{\text {cat }}$ values of MMLV RT obtained in this

12 study were 35 and $29 \mathrm{~s}^{-1}$, the reverse transcriptase activity of $\mathrm{K} 4 \mathrm{pol}_{\mathrm{L} 329 \mathrm{~A}}$ at around $65^{\circ} \mathrm{C}$

13 might be comparable to that of MMLV RT at $37^{\circ} \mathrm{C}$.

\section{Discussion}

The mechanism of the template-primer-mediated inhibition of reverse transcriptase activity is unclear. Because $\mathrm{K} 4 \mathrm{pol}_{\mathrm{L} 329 \mathrm{~A}}$ has the 3 ' -5 ' exonuclease domain but M1pol WT does not (Fig. 1), it is thought that the 3 ' -5 ' exonuclease domain is not critical for the inhibition. Bacterial family A DNA polymerases and retroviral RTs share a common structure: both groups comprise the fingers, palm, and thumb domains. Crystal structures of E. coli DNA polymerase [14], T. aquaticus DNA polymerase [15], human immunodeficiency virus type 1 (HIV-1) RT [16], and MMLV RT [17] revealed that the

24 palm domains are similar but the fingers and thumb domains are different between the 
1 two groups [18]: particular amino acid residues in $\alpha$-helix of the fingers domain are

2 involved in nucleotide binding in family A DNA polymerases while those in $\beta$-sheet of

3 the fingers domain are involved in RTs; and the sites in the thumb domain which

4 interact with the minor groove of the primer-template are different in the two groups.

5 There might be a possibility that the binding of template-primer with particular sites in

6 the fingers or thumb domain of family A DNA polymerase is involved in the inhibition.

7 The template-primer-mediated inhibition of reverse transcriptase activity suggests

8 that high concentrations of DNA-primed RNA template decrease the efficiency of

9 cDNA synthesis with bacterial family A DNA polymerases. We speculate that in RT-PCR, this inhibition affects the quantification, but does not much affect the detection of a target RNA. In clinical diagnosis, various nucleic acid tests are used for the detection of a target RNA from pathogens. Sauter and Marx generated T. aquaticus DNA polymerase variant, L322M/L459M/S515R/I638F/S739G/E773G/L789F, with increased reverse transcriptase activity by random mutation [19]. They showed that 0.1-5 ng of a target RNA can be quantified by the direct real-time RT-PCR with this variant enzyme in a single tube format [19]. This does not contradict our result because the concentration of $\mathrm{T} / \mathrm{P}$ is as high as $100 \mu \mathrm{M}$ (about $3 \mu \mathrm{g} / \mu \mathrm{L}$ ) in this study. To achieve the efficient synthesis of cDNA using bacterial family A DNA polymerases with reverse transcriptase activity, optimization is required for the concentration of T/P.

How are the template-primer-mediated inhibition of reverse transcriptase activities of K4pol and M1pol removed? If particular region involved in the T/P-mediated inhibition is identified, site-directed mutagenesis might be effective. Mayanagi et al. reported the structure of the ternary complex of family B DNA polymerase from hyperthermophilic archaeon Pyrococcus furiosus, proliferating cell nuclear antigen 
1 (PCNA), and DNA [20]. Shimada et al. reported that cold inducible RNA helicase from

2 hyperthermophilic archaeon Thermococcus kodakaraensis is critical for its adaptation to

3 cold temperature [21]. There is a possibility that molecules that interact with nucleic

4 acids, such as sliding clump, a ring-shaped protein that slides on DNA, and RNA

5 helicase, an enzyme that unwinds single-strand paired RNA, might be effective to

6 remove the inhibition. Removal of the inhibition will open up the wide application of

7 bacterial family A DNA polymerase in quantitative RT-PCR in a single tube format.

$9 \quad$ Acknowledgments

This study was supported in part (K.Y.) by Grants-in-Aid for Scientific Research

(nos. 19580104 and 21580110) from the Japan Society for the Promotion of Science and Daiwa Securities Health Foundation.

\section{References}

[1] G.F. Gerard, R.J. Potter, M.D. Smith, K. Rosenthal, G. Dhariwal, J. Lee, D.K. Chatterjee, The role of template-primer in protection of reverse transcriptase from thermal inactivation, Nucleic Acids Res., 30 (2002) 3118-3129.

B. Arezi, H. Hogrefe, Novel mutations in Moloney murine leukemia virus reverse transcriptase increase thermostability through tighter binding to template-primer, Nucleic Acids Res., 37 (2009) 473-481.

K. Yasukawa, M. Mizuno, A. Konishi, K. Inouye, Increase in thermal stability of Moloney murine leukaemia virus reverse transcriptase by site-directed 
mutagenesis, J. Biotechnol., 150 (2010) 299-306.

[4] A. Konishi, K. Yasukawa, K. Inouye, Improving the thermal stability of avian myeloblastosis virus reverse transcriptase $\alpha$-subunit by site-directed mutagenesis, Biotechnol. Lett., 34 (2012) 1209-1215.

[5] T.W. Myers, D.H. Gelfand, Reverse transcription and DNA amplification by a Thermus thermophilus DNA polymerase, Biochemistry, 30 (1991) 7661-7666.

[6] H. Shandilya, K. Griffiths, E.K. Flynn, M. Astatke, P.J. Shih, J.E. Lee, G.F. Gerard, M.D. Gibbs, P.L. Bergquist, Thermophilic bacterial DNA polymerases with reverse-transcriptase activity, Extremophiles, 8 (2004) 243-251.

[7] R. Kranaster, M. Drum, N. Engel, M. Weidmann, F.T. Hufert, A. Marx, Biotechnol. J., 5 (2010) 224-231.

[8] N.J. Schőnbrunner, E.H. Fiss, O. Budker, S. Stoffel, C.L. Sigua, D.H. Gelfand, T.W. Myers, Chimeric thermostable DNA polymerases with reverse transcriptase and attenuated 3'-5' exonulease activity, Biochemistry, 45 (2006) 12786-12795.

[9] S.J. Firbank, J. Wardle, P. Heslop, R.K. Lewis, B.A. Connolly, Uracil recognition in archaeal DNA polymerases captured by X-ray crystallography, J. Mol. Biol., 381 (2008) 529-538.

[10] S. Sano, Y. Yamada, T. Shinkawa, S. Kato, T. Okada, H. Higashibata, S. Fujiwara, Mutations to create thermostable reverse transcriptase with bacterial family A DNA polymerase from Thermotoga petrophila, J. Biosci. Bioeng., 113 (2012) 315-321.

[11] M.M. Bradford, A rapid and sensitive method for the quantitation of microgram quantities of protein utilizing the principle of protein-dye binding, Anal. Biochem., 72, 248-254 (1976). 
1 [12] K. Bebenek, T.A. Kunkel, Analyzing fidelity of DNA polymerases, Methods

2 Enzymol., 262 (1995) 217-232.

[13] V. Barrioluengo, M. Álvarez, D. Barbieri, L. Menéndez-Arias, Thermostable HIV-1 group O reverse transcriptase variants with the same fidelity as murine leukaemia virus reverse transcriptase, Biochem. J., 436 (2011) 599-607.

[14] L.S. Beese, V. Derbyshire, T.A. Steitz, Structure of DNA polymerase I Klenow fragment bound to duplex DNA, Science, 260 (1993) 352-355.

[15] S.H. Eom, J. Wang, T.A. Steitz, Structure of Taq polymerase with DNA at the polymerase active site, Nature, 382 (1996) 278-281.

[16] L.A. Kohlstaedt, J. Wang, J.M. Friedman, P.A. Rice, T.A. Steitz, Crystal structure at $3.5 \AA$ resolution of HIV-1 reverse transcriptase complexed with an inhibitor, Science, 256 (1992) 1783-1790.

[17] D. Das, M.M. Georgiadis, The crystal structure of the monomeric reverse transcriptase from Moloney murine leukemia virus, Structure, 12 (2004) 819-829.

[18] T.A. Steitz, DNA polymerases: Structural diversity and common mechanism, J. Biol. Chem., 274 (1999) 17395-17398.

[19] K.B. Sauter, A. Marx, Evolving thermostable reverse transcriptase activity in a DNA polymerase scaffold, Angew. Chem. Int. Ed., 45 (2006) 7633-7635.

[20] K. Mayanagi, S. Kiyonari, H. Nishida, M. Saito, D. Kohda, Y. Ishino, T. Shirai, K. Morikawa, Architecture of the DNA polymerase B-proliferating cell nuclear antigen (PCNA)-DNA ternary complex, Proc. Natl. Acad. Sci. USA, 108 (2011) 1845-1849.

[21] Y. Shimada, W. Fukuda, Y. Akada, M. Ishida, J. Nakayama, T. Imanaka, S. 
Fujiwara, Property of cold inducible DEAD-box RNA helicase in

2

hyperthermophilic archaea, Biochem. Biophys. Res. Commun., 389 (2009)

3 $622-627$.

4 
1

2

4

5

\section{Figure legends}

Fig. 1. Creation of reverse transcriptase activity in K4pol by the mutation of Leu329 $\rightarrow$ Ala. (A) Domain structure of bacterial DNA polymerases. (B-D) Modeled structure of K4pol-template RNA complex. The structure is constructed by Swiss model using E. coli Klenow fragment $(1 \mathrm{kfs})$ as a template. Carbon, nitrogen, oxygen, and phosphorus atoms of RNA are shown in green, blue, red, and orange, respectively. (B) Whole structure of $\mathrm{K} 4 \mathrm{pol}_{\mathrm{WT}}$-template RNA complex. The amino acid residues predicted to be located around an RNA template (Tyr326, Leu329, Gln384, Lys387, Phe388, Met408, Asn422, Tyr438, and Phe451) are shown in green. (C) Close-up view of Leu329 of K4polwT-template RNA complex. (D) Close-up view of Ala329 of $\mathrm{K}_{\text {4pol }}$ 329A-template RNA complex. Electron densities of the side chain of Leu329 (C) and Ala329 (D) are shown in red.

Fig. 2. DNA- and RNA-dependent DNA polymerase activities of K4pol ${ }_{\mathrm{L} 329 \mathrm{~A}}$. (A) SDS-PAGE under reducing condition. Lane M, molecular-mass marker. (B) Agarose gel electrophoresis of reaction products in the DNA-dependent DNA polymerase assay. Lane M, molecular-mass marker. The DNA bands a, b, c, and d correspond to the gap-filled DNA, the gapped DNA (the annealing product of the 6,789-base single-strand DNA fragment and the 7,196-base single-strand circular DNA), the 6,789-bp double-strand DNA fragment, and the 7,196-base single-strand circular DNA, respectively. The reaction was carried out with $670 \mathrm{nM} \mathrm{K} 4 \mathrm{pol}_{\mathrm{L} 329 \mathrm{~A}}$ at $50^{\circ} \mathrm{C}$ for $5 \mathrm{~min}$. (C) Incorporation of radioactivity of reaction products in the reverse transcriptase assay. The reaction was carried out with $\mathrm{K} 4 \mathrm{pol}_{\mathrm{WT}}\left(50 \mathrm{nM}\right.$ at $\left.50^{\circ} \mathrm{C}\right), \mathrm{K}_{4} \operatorname{pol}_{\mathrm{L} 329 \mathrm{~A}}(50 \mathrm{nM}$ at 
$\left.150^{\circ} \mathrm{C}\right), \mathrm{M} 1 \mathrm{pol}_{\mathrm{WT}}\left(50 \mathrm{nM}\right.$ at $\left.50^{\circ} \mathrm{C}\right)$ or $\mathrm{MMLV} \mathrm{RT}\left(2 \mathrm{nM}\right.$ at $\left.37^{\circ} \mathrm{C}\right)$. The initial

2 concentrations of $\mathrm{dTTP}$ and T/P were 200 and $10 \mu \mathrm{M}$, respectively.

3

4 Fig. 3. Substrate dependence of the reaction rates $\left(v_{0}\right)$ in the reverse transcriptase

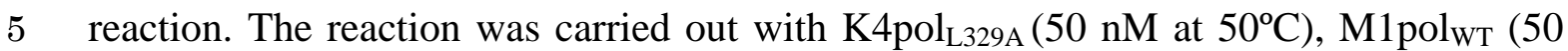

$6 \mathrm{nM}$ at $\left.50^{\circ} \mathrm{C}\right)$ or MMLV RT $\left(2 \mathrm{nM}\right.$ at $\left.37^{\circ} \mathrm{C}\right)$. Solid line represents the best fit of the

7 Michaelis-Menten equation. (A) Dependence of $v_{\mathrm{o}}$ on the dTTP concentration. The

8 initial T/P concentration was $10 \mu \mathrm{M}$. (B) Dependence of $v_{\mathrm{o}}$ on the T/P concentration.

9 The initial concentration of dTTP was $200 \mu \mathrm{M}$.

10

11 Fig. 4. Temperature dependence of the reaction rate $\left(v_{\mathrm{o}}\right)$ of $\mathrm{K} 4 \mathrm{pol}_{\mathrm{L} 329 \mathrm{~A}}$ in the reverse transcriptase reaction. The reaction was carried out with $50 \mathrm{nM} \mathrm{K} 4 \mathrm{pol}_{\mathrm{L} 329 \mathrm{~A}}$. The initial concentrations of dTTP and T/P were 200 and $25 \mu \mathrm{M}$, respectively. Inset shows

14 Arrhenius plot. 
A

Family $\mathrm{A}-\left[\begin{array}{c}\text { Thermus thermophilus } \mathrm{M} 1 \\ \text { Thermotoga petrophila } \mathrm{K} 4\end{array}\right.$ Thermococcus kodakarensis
Family $\mathrm{B} \quad \mathrm{N}-\mathrm{C}$

B

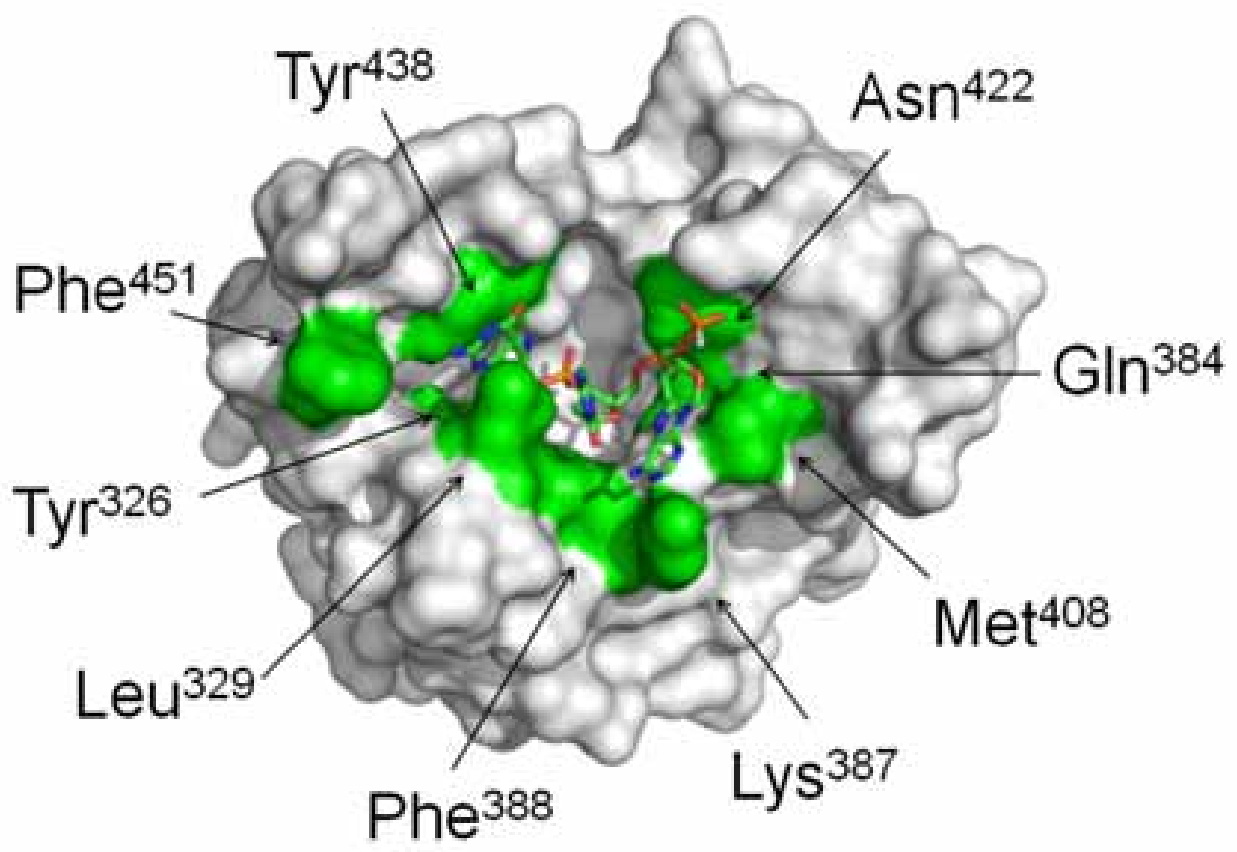

C

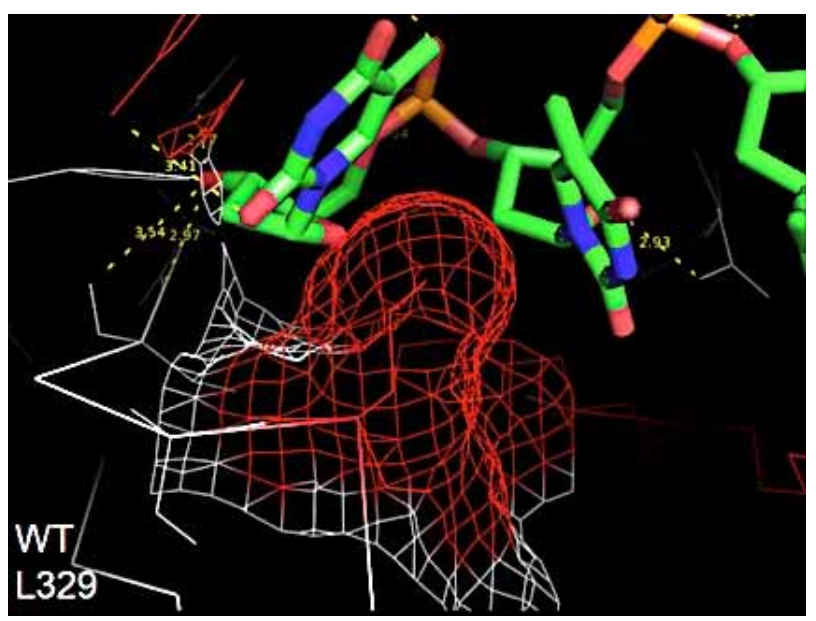

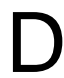

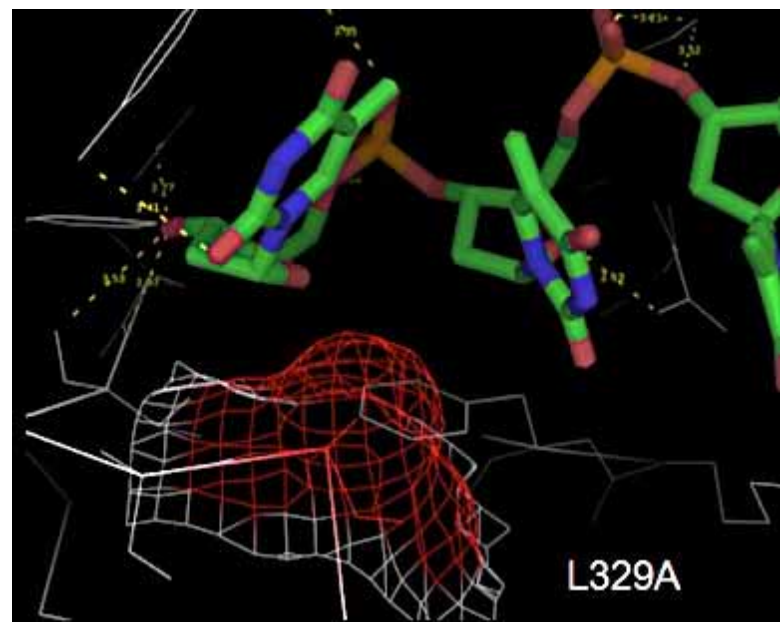

Fig. 1, Yasukawa et al. 
A

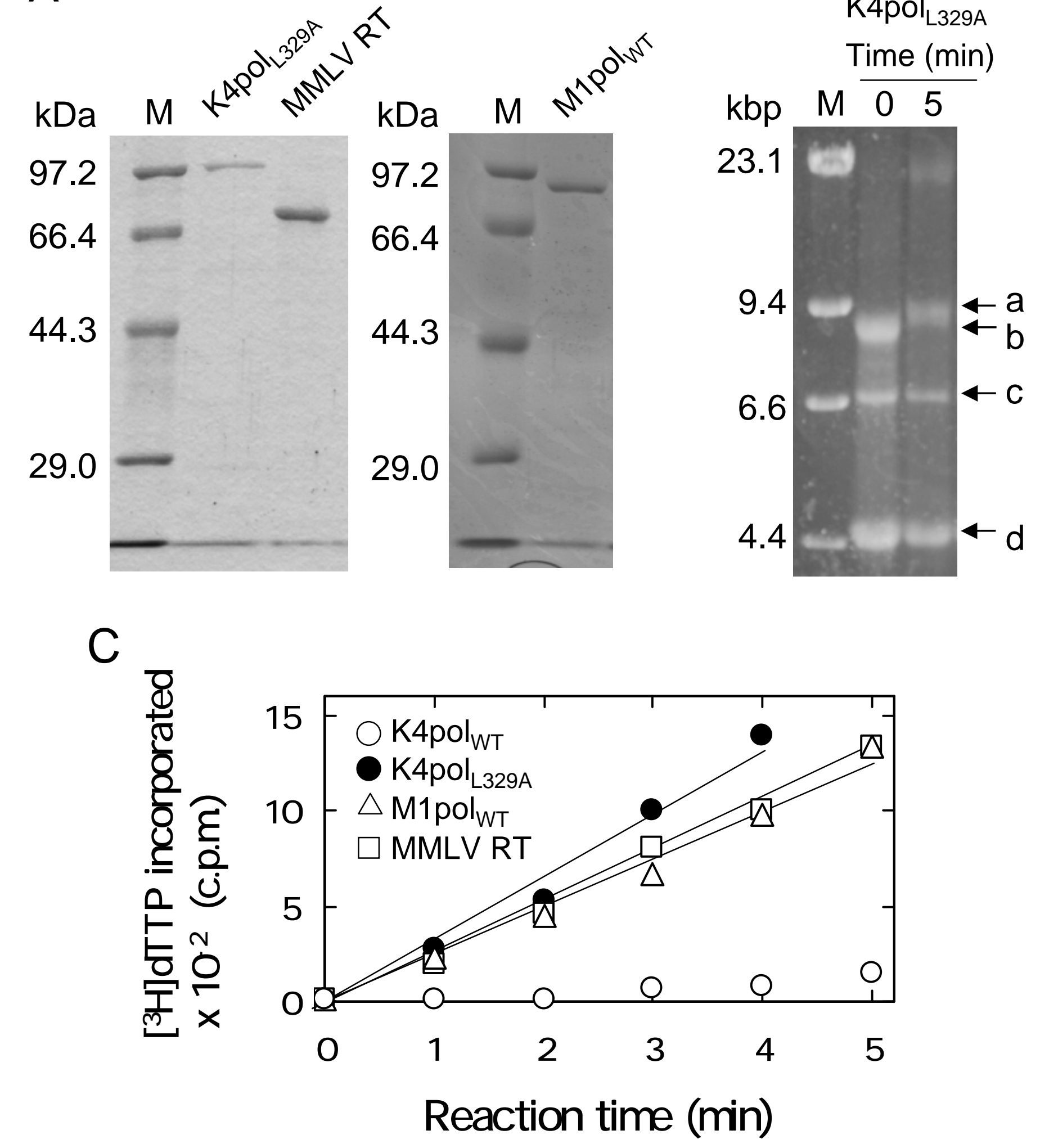

Fig. 2, Yasukawa et al. 
A
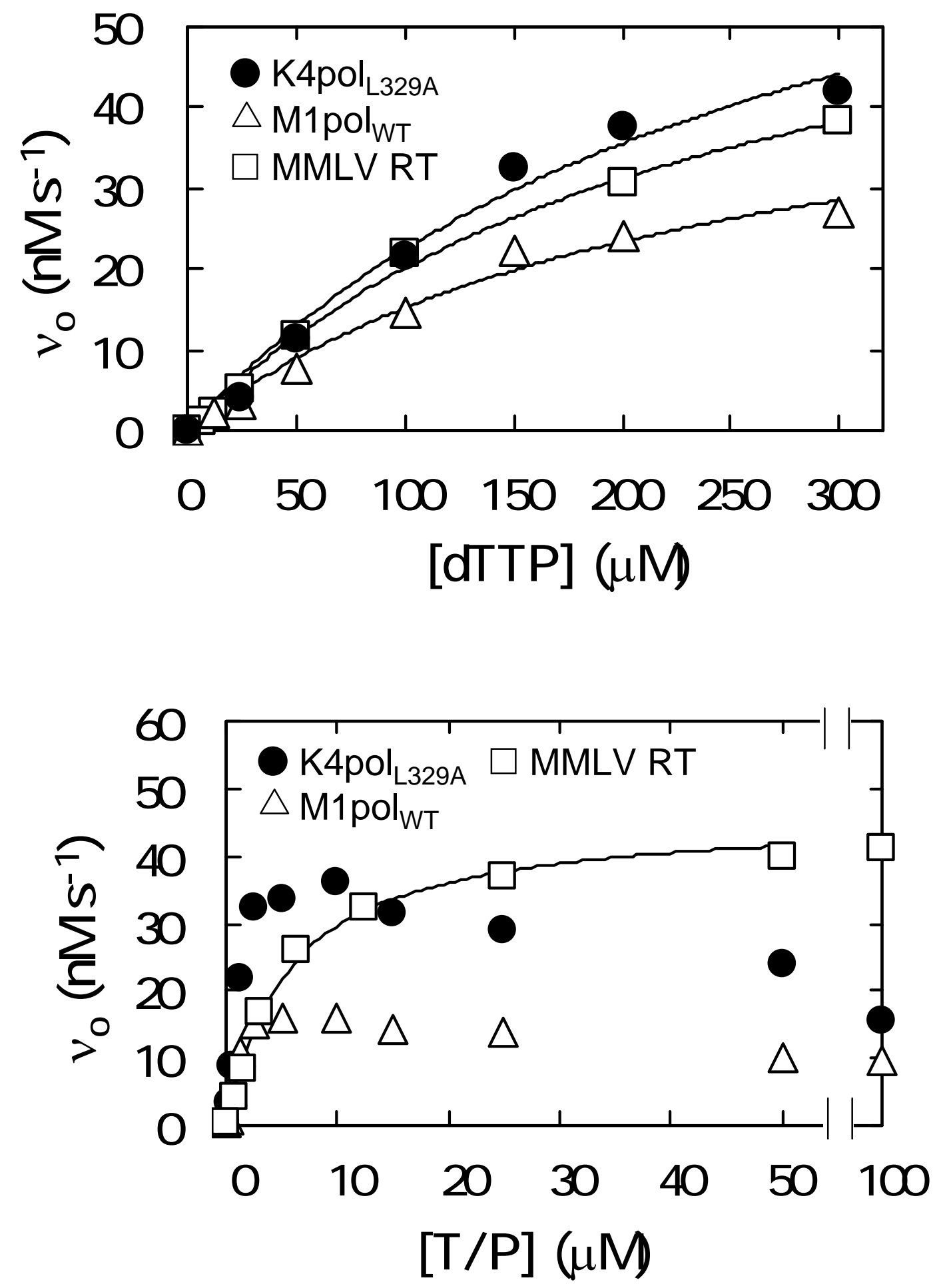

Fig. 3, Yasukawa et al. 


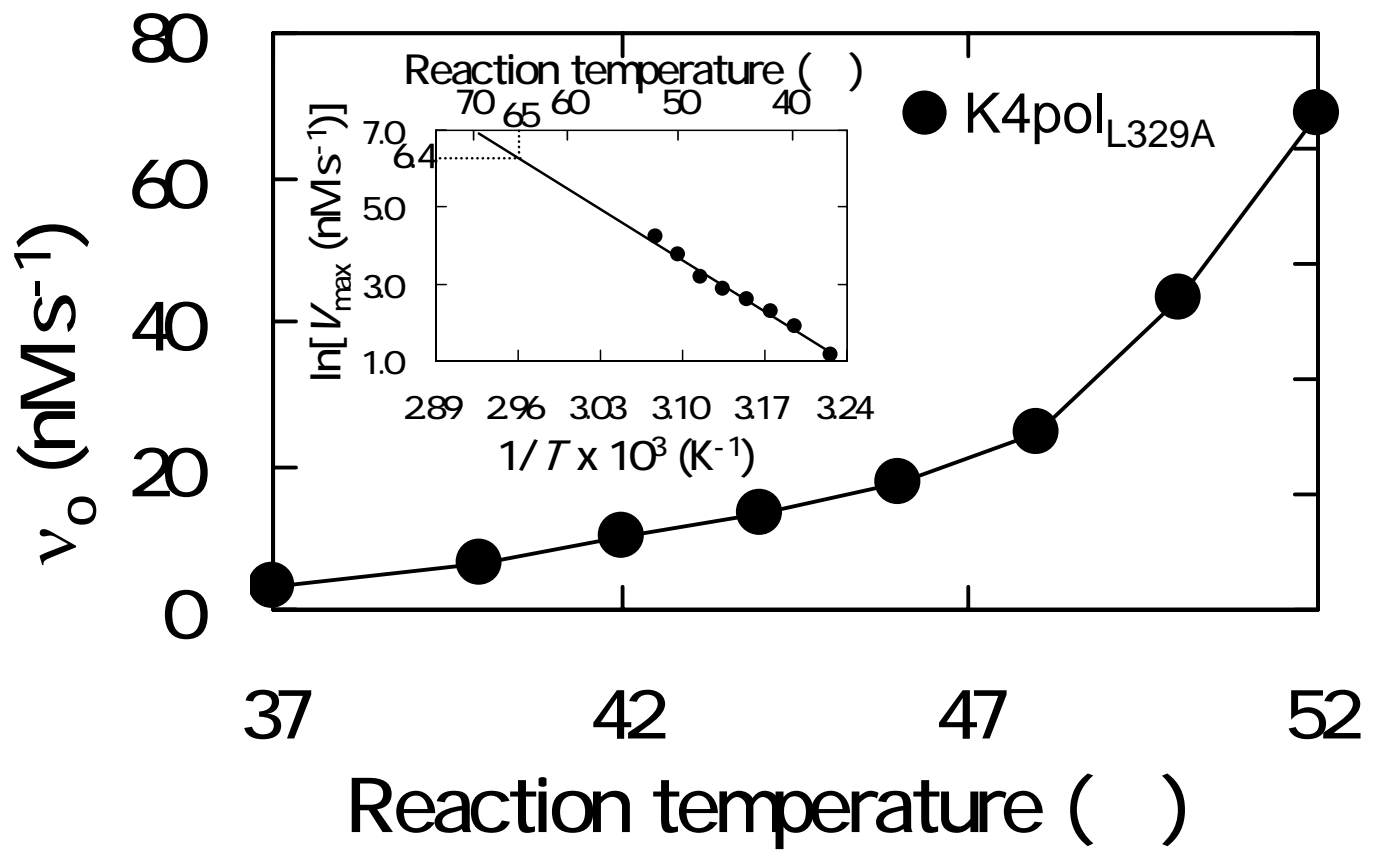

Fig. 4, Yasukawa et al. 